\title{
Improvement in strength calculation for pavement structure of rail station areas
}

\author{
Vladimir Mozgovyi ${ }^{1, *}$, Sergei Baran ${ }^{1}$, and Alexander Kutsman ${ }^{1}$ \\ ${ }^{1}$ National Transport University, Road Construction Materials and Chemistry Department, \\ Boychuka st. 42M, 01103 Kyiv, Ukraine
}

\begin{abstract}
The paper discusses the issue of how to increase the durability of road pavements at stations. At the same time, the behavior of asphaltconcrete layers is considered taking into account thermoreological properties and their materials. An increased duration of traffic loads on station areas influences changes in strength and rigidity characteristics of the asphalt concrete. Mathematical models to increase the accuracy of strength calculation of pavement designs on station areas have been developed.
\end{abstract}

Nowadays the most common material used as the pavement of city streets and squares is the asphalt concrete. However, strength and durability of such a coating on station areas are considerably lower in comparison with these characteristics for sections of streets and roads of intensive traffic. The research conducted by the authors showed that an increase in continuous loads on the asphalt concrete pavement causes its more intensive destruction.

In accordance with the normative design procedure for asphalt concrete pavement under Branch Construction Norms VBN B.2.3-218-186 [1], $0.1 \mathrm{sec}$ is the design loading duration which corresponds to the average speed of movement for design vehicles on generalpurpose roads. At the same time, the traffic on station areas significantly differs from the traffic on public roads. The traffic mode on station areas is characterised by lower speeds, longer stops and parking, which causes an increased loading duration, as well as a change in the properties of thermo-rheological sensitive materials.

An assessment of an effect of design characteristics of asphalt concretes on the stressstrain state and durability of the pavement covering under multiple static and short-term loads was made on the basis of work [2]. Consequently, it was proved that longer loads resulted in lower coefficient of elasticity of asphalt concretes (Table 1) and other materials, which led to a decrease in the maximum horizontal tensile stresses in the upper layer of the base of asphalt concrete. And values of the tensile strength in bending $R_{b e n}$ of the material in which $\sigma_{\max }$ occur increase (Table 1).

It should also be taken into account that the tensile strength at bending $R_{b e n}$ with an increase in the loading duration decreases much faster than the maximum horizontal tensile stresses $\sigma_{m a x}$. It is exactly the reason why fatigue cracks appear prematurely on the sections where heavy vehicles slow down very frequently.

\footnotetext{
*Corresponding author: mozgoviy@gmail.com
} 
Table 1. Deformation and strength characteristics of the highly porous asphalt concrete on Road Bitumen 60/90 under various loading duration.

\begin{tabular}{|l|l|l|l|l|}
\hline \multirow{2}{*}{ Design characteristics } & \multicolumn{4}{|c|}{ Loading duration, sec } \\
\cline { 2 - 5 } & 0.1 & 1.0 & 10.0 & 600.0 \\
\hline Modulus of elasticity, MPa & 2100 & 1510 & 1050 & 510 \\
\hline Tensile strength at bending, $R_{\text {ben. }}, \mathrm{MPa}$ & 5.65 & 3.18 & 1.79 & 0.64 \\
\hline
\end{tabular}

For the analysis the comparative calculations of soft pavement with black rubble as the base and the pavement of the same strength with cemented crushed stone as foundation was conducted.

The results of the calculation regarding the applied design load before the pavement deterioration (relative durability) are given in Table 2.

Table 2. Relative durability of road pavement.

\begin{tabular}{|c|c|c|}
\hline $\begin{array}{c}\text { Type of road } \\
\text { pavement }\end{array}$ & $\begin{array}{c}\text { Loading duration, } \\
t, \mathrm{sec}\end{array}$ & $\begin{array}{c}\text { Relative durability, } \\
N(t) / N(t=0.1 \mathrm{sec})\end{array}$ \\
\hline Not reinforced & 0.1 & 1 \\
& 1 & 0.305 \\
& 10 & 0.170 \\
& 100 & 0.108 \\
\hline Reinforced & 0.1 & 1 \\
& 1 & 0.314 \\
& 10 & 0.175 \\
& 100 & 0.138 \\
\hline
\end{tabular}

Table 2 shows that the number of the design load application before the pavement destruction decreases with an increase in the loading duration. Besides, it can be concluded that strengthened base slightly increases its durability, and to a greater extent with a longer duration of the load.

Thus, the study conducted shows that durability of the asphalt-concrete coating of nonrigid road pavement significantly decreases with an increased loading duration. And the durability of asphalt-concrete coating considerably depends on the thermoreological sensitivity of the base materials.

Let us consider in more detail the influence of these factors on durability of asphaltconcrete coating for non-rigid road pavements with bases of various thermoreological sensitivity by examples of loading regimes typical for the areas characterised by slow traffic and stops of vehicles.

Taking into account the well-known fact that loading duration, temperature and humidity influence the deformation and strength characteristics of road pavement materials according to their composition and structure, the authors proposed a classification of materials by their thermoreological sensitivities. In this case, the ratio of instantaneous and long moduli of elasticity was taken as an indicator of thermoreological sensitivity. Thus, road construction materials were divided into four groups (Table 3 ).

By the method described in $[6,7]$ the research into the durability of non-rigid road pavements with asphalt-concrete coatings of different base models according to their thermoreological sensitivity and the same strength criteria by method [1] (Fig. 1) was conducted.

The obtained results show that these road pavements have different durability when a loading duration increases (Fig. 1).

The research conducted shows that for the roads of slow traffic and stops of vehicles, the use of materials of lower thermoreological sensitivity for the base of road pavement contributes to a significant increase in the pavement durability (2-5 times or more). 
Table 3. Groups of road building materials by the thermoreological sensitivity.

\begin{tabular}{|l|l|l|l|}
\hline \multicolumn{4}{|c|}{ Types of road construction materials by groups } \\
\hline \multicolumn{1}{|c|}{$\begin{array}{l}\text { I } \\
\text { (Highly sensitive) }\end{array}$} & \multicolumn{1}{|c|}{$\begin{array}{c}\text { II } \\
\text { (Sensitive) }\end{array}$} & $\begin{array}{c}\text { III } \\
\text { (Moderately } \\
\text { sensitive) }\end{array}$ & \multicolumn{1}{c|}{$\begin{array}{c}\text { IV } \\
\text { (Poorly sensitivity) }\end{array}$} \\
\hline $\begin{array}{l}\text { Asphalt-concrete } \\
\text { of all types, } \\
\text { organomineral } \\
\text { mixtures, etc. }\end{array}$ & $\begin{array}{l}\text { Clay and silty } \\
\text { roadbeds, crushed } \\
\text { stone and gravel, } \\
\text { treated with organic } \\
\text { binders, etc. }\end{array}$ & $\begin{array}{l}\text { Crushed stone, } \\
\text { gravel, sand, } \\
\text { untreated or treated } \\
\text { with mineral binders } \\
\text { of less than 5\%, } \\
\text { sandy and sandy } \\
\text { loam soils and } \\
\text { gravel-sand } \\
\text { mixtures treated } \\
\text { with mineral } \\
\text { binders, etc. }\end{array}$ & $\begin{array}{l}\text { Crushed stone, } \\
\text { gravel, sand, coarse- } \\
\text { grained soils and } \\
\text { gravel-sand mixtures } \\
\text { treated with mineral } \\
\text { binders in an amount } \\
\text { of more than 5\%, lean } \\
\text { concrete, etc. }\end{array}$ \\
\hline
\end{tabular}

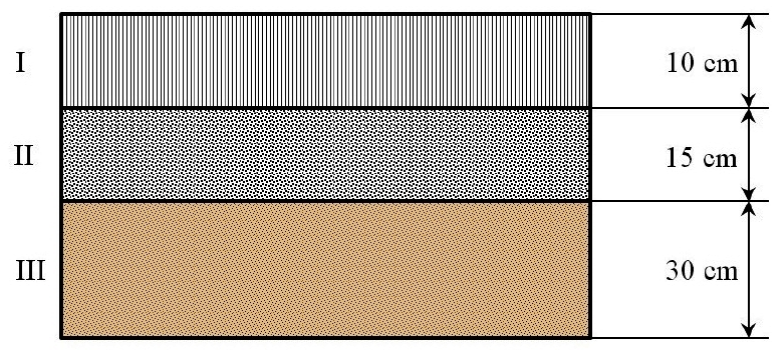

(a)

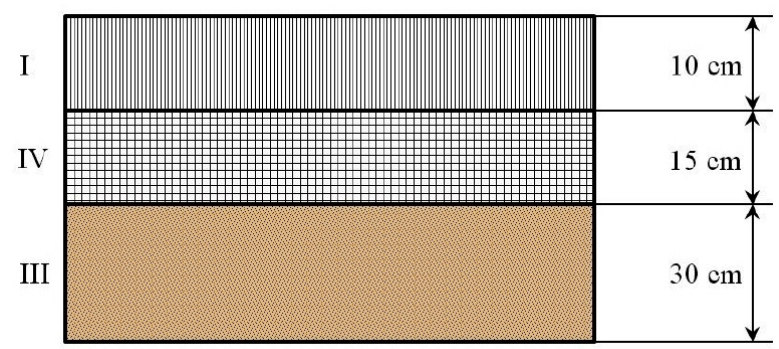

(b)

Fig. 1. Road pavements equivalent to the traditional criteria of the limiting state: (a) with a base of materials of increased thermoreological sensitivity $\left(1^{\text {st }}\right.$ variant $)$; (b) the same of reduced thermoreological sensitivity $\left(2^{\text {nd }}\right.$ variant $)$.

Thus, the conducted researches allow offering more perfect models of asphalt-concrete coatings taking into account the different loading duration on various base models containing materials of various thermoreological sensitivity.

In connection with the above mentioned, the following is suggested.

For calculation of asphalt concrete pavements on station areas it is advisable to produce the complex multiple impact as short-term loading $\left(t_{l}=1.0 \mathrm{sec}\right)$ and static loading $\left(t_{1}=600\right.$ sec). 
For such a combination of binary loading we use the fundamental propositions of the kinetic theory of strength of solids [2, 3-5] when considering the issue of the asphalt concrete pavement durability.

In this case using Miner's rule changes in relative durability expressed as the measure of damageability $M$ from each binary loading cycle can be written as the following dependence:

$$
\begin{aligned}
& \qquad M=M_{1}\left(\sigma_{1}\left(t_{l}=1.0 \mathrm{~s}\right)+M_{2}\left(\sigma_{2}\left(t_{l}=600 \mathrm{~s}\right)<1,\right.\right. \\
& \text { where } \quad M_{1}=\frac{n\left(t_{l}=1.0 \mathrm{~s}\right)}{\sum N_{p 1}\left(t_{l}=1,0 \mathrm{~s}\right)} ; M_{2}=\frac{n\left(t_{l}=600 \mathrm{~s}\right)}{\sum N_{p 2}\left(t_{l}=600 \mathrm{~s}\right)} .
\end{aligned}
$$

Under the combined influence of the binary cycle on fatigue destruction of asphalt concrete pavements at the known values $\sum N_{p}$ of loading units and the share $\delta_{2}$ in the total number of loads $\sum N_{p}$ from vehicles creating the loading duration $t_{\mathrm{H}}>1.0 \mathrm{sec}$ and determined on the basis of the feasibility studies the following expressions will be true:

$$
N_{1}+N_{2}=\Sigma N ; \quad N_{1}=\left(1-\delta_{2}\right) \cdot \Sigma N ; \quad \delta_{2}=\frac{N_{2}}{\Sigma N} .
$$

Therefore, the above calculation testify that for the corresponding loading regimes the limiting quantity of loads on the non-rigid asphalt concrete pavement for the binary cycle of loading at $\mathrm{t}_{11}=1.0 \mathrm{sec}$ and $\mathrm{t}_{12}=600 \mathrm{sec}$ can be established.

With the help of this technique, the calculations of road pavement structure with asphalt concrete pavement were conducted.

The structure includes the following layers:

- dense asphalt concrete on Road Bitumen 60/90, a thickness of $40 \mathrm{~mm}$;

- $\quad$ porous asphalt concrete on Road Bitumen 60/90, a thickness of $80 \mathrm{~mm}$;

- $\quad$ highly porous asphalt concrete on Road Bitumen 60/90, a thickness of $220 \mathrm{~mm}$;

- $\quad$ crushed-gravel-sandy mixture, treated with cement M20, a thickness of $260 \mathrm{~mm}$;

- $\quad$ soil road bed - dusty sandy loam.

Preliminary strength calculation in accordance with [1] for a design loading duration of $0.1 \mathrm{sec}$ showed that the selected design met all strength criteria. However, with an increase in the loading duration on pavements from $0.1 \mathrm{sec}$ to $1 \mathrm{sec}$, in accordance with the proposed procedure, the calculation results showed that the chosen design did not satisfy the criterion of tensile strength at bending, which requires the introduction of appropriate adjustments. Due to correction, it turned out that in order to compensate for the decrease in the strength coefficient with an increased loading duration from $0.1 \mathrm{sec}$ to $1 \mathrm{sec}$ it is efficient to replace the highly porous asphalt concrete with dense asphalt concrete of increased strength and resistance to repeated loads. Similar results were obtained when calculating the structure for 600 -sec duration.

Therefore, in order to ensure the necessary strength and increased durability of asphaltconcrete layers for pavement on rail station areas it is reasonable to replace the bending material in a layer with a material of increased strength and resistance to repeated loadings.

\section{References}

1 Transport facilities. Flexible type of pavement.VBNV.2.3-218-186-2004 
2 V.V. Mozgovyi, Scientific foundations for ensuring the temperature crack resistance of asphalt concrete coatings: dis. for the degree of Doctor of Technical Sciences. Kiev, (1996)

3 A.A. Ilyushin, On a theory of long-term strength Engineering Journal MTT,3(1967).

4 A.A. Ilyushin, B.E. Pobedrya, Fundamentals of the mathematical theory of thermoviscoelasticity (Science, Kiev, 1970)

5 V.V. Moskvitin, Resistance of viscoelastic materials (Science, Kiev, 1972)

6 V. Smolyanets, Improving the design of non-rigid asphalt pavement in a city: dis. for the degree of Ph.D. (Kiev, 2005)

7 L.A. Mozgovaya, A.V. Mozgovoy, V.V. Mozgovoy and others, Road engineering, 126-139 (2007) 